\title{
Filling a gap in the distribution of Batrachochytrium dendrobatidis: evidence in amphibians from northern China
}

\author{
Wei Zhu ${ }^{1,2, *}$, Liqing Fan ${ }^{3, *}$, Claudio Soto-Azat ${ }^{4}$, Shaofei Yan ${ }^{1,2,5}$, Xu Gao ${ }^{1,2}$, \\ Xuan Liu ${ }^{1}$, Supen Wang ${ }^{1,2}$, Conghui Liu $^{1,2}$, Xuejiao Yang ${ }^{1,2}$, Yiming $\mathrm{Li}^{1, * *}$
}

\author{
${ }^{1}$ Key Laboratory of Animal Ecology and Conservation Biology, Institute of Zoology, Chinese Academy of Sciences, \\ Beijing 100101, PR China \\ ${ }^{2}$ University of Chinese Academy of Sciences, 19 Yuquan Road, Beijing 100049, PR China \\ ${ }^{3}$ Institute of Plateau Ecology, Agriculture and Animal Husbandry College of Tibet University, No. 8 Xueyuan Street, \\ Bayi Town, Linzhi County, Xizang Province 860000, PR China \\ ${ }^{4}$ Centro de Investigación para la Sustentabilidad, Facultad de Ecologia y Recursos Naturales, Universidad Andres Bello, \\ Republica 440, Santiago 8370251, Chile \\ ${ }^{5}$ Department of Ecology, School of Resources \& Engineering, Anhui University, Hefei 230601, PR China
}

\begin{abstract}
Chytridiomycosis caused by Batrachochytrium dendrobatidis $(B d)$ has been recognized as a major driver of amphibian declines worldwide. Central and northern Asia remain as the greatest gap in the knowledge of the global distribution of $B d$. In China, $B d$ has recently been recorded from south and central regions, but areas in the north remain poorly surveyed. In addition, a recent increase in amphibian farming and trade has put this region at high risk for $B d$ introduction. To investigate this, we collected a total of 1284 non-invasive skin swabs from wild and captive anurans and caudates, including free-ranging, farmed, ornamental, and museumpreserved amphibians. $B d$ was detected at low prevalence $(1.1 \%, 12$ of 1073$)$ in live wild amphibians, representing the first report of $B d$ infecting anurans from remote areas of northwestern China. We were unable to obtain evidence of the historical presence of $B d$ from museum amphibians $(\mathrm{n}=72)$. Alarmingly, $B d$ was not detected in wild amphibians from the provinces of northeastern China (> 700 individuals tested), but was widely present $(15.1 \%, 21$ of 139 ) in amphibians traded in this region. We suggest that urgent implementation of measures is required to reduce the possibility of further spread or inadvertent introduction of $B d$ to China. It is unknown whether $B d$ in northern China belongs to endemic and/or exotic genotypes, and this should be the focus of future research.
\end{abstract}

KEY WORDS: Chytridiomycosis · Andrias davidianus $\cdot$ Museum specimens · Asia

\section{INTRODUCTION}

Chytridiomycosis caused by the chytrid fungus Batrachochytrium dendrobatidis $(B d)$ has been identified as a major driver of global amphibian population declines (Berger et al. 1998, Daszak et al. 2003, Walker et al. 2008, Cheng et al. 2011). Bd infects at least 695 species of amphibians (anurans, salaman- ders, and caecilians) from all continents where they exist and has been implicated in the enigmatic disappearance of many frog species in Australia, Europe, and North, Central, and South America (Berger et al. 1998, Lips et al. 2006, Walker et al. 2008, Vredenburg et al. 2010, Cheng et al. 2011, Soto-Azat et al. 2013, Olson \& Ronnenberg 2014). However, negative impacts at the population level on other regions 
where $B d$ exists, such as Asia and Africa, have not been recorded (Kusrini et al. 2008, Goka et al. 2009, Yang et al. 2009, Bai et al. 2010, 2012, Soto-Azat et al. 2010, Savage et al. 2011, Swei et al. 2011). One possible explanation is that $B d$ is endemic in some areas but novel in others (Rosenblum et al. 2013). The endemic lineage BdAsia has been identified in China (Bai et al. 2012), Japan (Goka et al. 2009), and South Korea (Bataille et al. 2013).

$B d$ has been recently introduced to many regions, including Central America (Cheng et al. 2011, VeloAnton et al. 2012), California, USA (Vredenburg et al. 2010, 2013), Australia (Skerratt et al. 2007, Murray et al. 2010), and Madagascar (Bletz et al. 2015), while in other regions, it has been present for a long time. For instance, Rodriguez et al. (2014) proposed that 2 lineages of $B d$ (BdGPL and BdBrazil) have been present in Brazil for more than $120 \mathrm{yr}$, and Rosenblum et al. (2013) suggested that BdGPL emerged at least 1000 yr ago. For Africa, the earliest known Bd-positive cases were confirmed in amphibians collected in the early 1930s (Soto-Azat et al. 2010). For Asia, the earliest detection of $B d$ by PCR was in samples collected in 1911 from the Korean Peninsula, although in Japan, evidence of $B d$ infection based on histology dates back to 1902 (Schloegel et al. 2012, Fong et al. 2015). Globally, the earliest known record of $B d$ infection found in a museum retrospective study is from a specimen of Rana sphenocephala collected in Illinois, USA, in 1888 (Talley et al. 2015).

In Asia, $B d$ has been described infecting wild and captive amphibians from many countries, including China, Japan, South Korea, Indonesia, Malaysia, Laos, Philippines, Sri Lanka, Kyrgyzstan, Vietnam, and India (Kusrini et al. 2008, Une et al. 2008, Goka et al. 2009, Yang et al. 2009, Bai et al. 2010, 2012, Savage et al. 2011, Swei et al. 2011, Bataille et al. 2013, Dahanukar et al. 2013, Zhu et al. 2014a). Nevertheless, extensive areas of central, northern, and western mainland Asia still lack information on the presence and impacts of Bd (Olson et al. 2013, Olson \& Ronnenberg 2014). In China, Bd has been reported from 10 central and southern provinces of the country (Bai et al. 2010, 2012, Zhu et al. 2014a,b), with northern regions remaining poorly surveyed for the occurrence of this emerging disease.

Northeastern China is a mountain- and forest-dominated landscape and is bordered by Russia and North Korea. Here, amphibian diversity reaches 15 species (Fei et al. 2010). Two studies, one based on 191 R. dybowskii sampled from Heilongjiang Province in China (Wei et al. 2010), and the other based on 180 individuals of 3 amphibian species from the far eastern Russian Federation (Civis et al. 2013), have only found $B d$-negative results. The northwestern region of China is an arid to semi-arid area, so the presence of amphibians here is limited to rivers, ponds, rice fields, and other natural wetlands. This region belongs to the mountains of Central Asia, and is considered 1 of the 35 global biodiversity hotspots (Mittermeier et al. 2011). To the north, this region borders Russia, Mongolia, and Kazakhstan, and Bd has not been previously surveyed in this vast territory.

Animal food markets and farms are considered critical for disease emergence and spread through the circulation of pathogens and host species (Li \& Li 1998, Garner et al. 2006, Schloegel et al. 2009, Liu et al. 2013a). Many amphibians are commonly traded as food or for ornamental purposes, particularly around the most populous cities of China (Liu \& Li 2009, Liu et al. 2012). The Critically Endangered Chinese giant salamander Andrias davidianus is raised for food in many provinces of China, such as Shaanxi, Zhejiang, and Beijing (Liang et al. 2004). The North American bullfrog Lithobates catesbeianus is widely raised for food in farms, from which it has escaped and has established feral populations in many regions across China (Li et al. 2006, 2011, Liu \& Li 2009, Liu et al. 2012, 2013a). Other species, such as the Mexican axolotl Ambystoma mexicanum, the African clawed frog Xenopus laevis, and the Asiatic grass frog $R$. chensinensis are commonly traded in pet shops for ornamental purposes and are captive-bred in China. The latter 2 species are also commonly acquired to feed Asian arowana Scleropages formosus, a widely traded fish in Beijing. Unlike A. mexicanum and $X$. laevis, $R$. chensinensis is native to northern China.

To investigate the current and past distribution of $B d$ in northern China and to assess the potential role of invasive and traded amphibians as disease vectors, we investigated 1284 native and invasive anurans and caudates including free-ranging, farmed, ornamental, and museum-preserved amphibians for evidence of $B d$ infection.

\section{MATERIALS AND METHODS}

\section{Wild amphibians}

Sampling was conducted in 8 provinces (Fig. 1) throughout northern China from 2012 to 2014 . A total of 1073 samples representing 19 species were collected during spring and autumn from various types of habitats, including park ponds, ephemeral pud- 


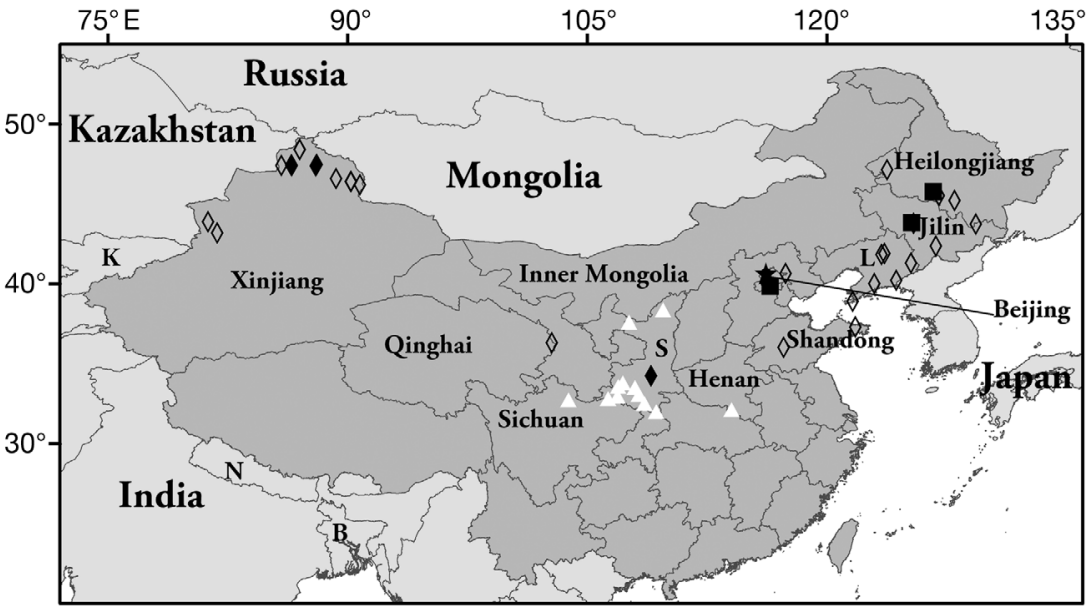

Fig. 1. Distribution of 1284 amphibians sampled from northern China surveyed for the presence of Batrachochytrium dendrobatidis. Rhombuses indicate wild amphibians; squares indicate amphibians from markets and pet shops; star represents amphibians farmed for food. Closed symbols indicate sites where $B d$ was detected. White triangles indicate sites where archived amphibians were collected. B: Bangladesh; K: Kyrgyzstan; N: Nepali L: Liaoning Province; S: Shaanxi Province

\section{Sampling}

All individual amphibians (wild, captive, and museum specimens) were sampled using the non-invasive skin swab technique described by Hyatt et al. (2007). To prevent cross-contamination, each sample was handled using a new pair of disposable gloves. In addition, for museum specimens preserved in jars containing 2 or more individuals, each was rinsed with $70 \%$ EtOH before sampling. All swabs were preserved in $70 \% \mathrm{EtOH}$ in $1.5 \mathrm{ml}$ centrifuge tubes and were ultimately stored at $-20^{\circ} \mathrm{C}$ in the laboratory. For samples obtained from wild amphibians, strict biosecurity protocols were followed, including washing, disinfecting, and drying all equipment before entering a new location (Phillott et al. 2010).

\section{Laboratory analysis} ponds, and natural wetlands. In addition to native species, we also collected free-ranging Lithobates catesbeianus, which have successfully invaded wide areas of China. All sampled amphibians were adults.

\section{Farmed and traded amphibians}

Fifty-two individual amphibians of 4 widely traded species, viz. L. catesbeianus, Ambystoma mexicanum, Xenopus laevis, and Rana chensinensis, were sampled from 1 food market and 2 pet shops in Beijing during the winter of 2013 and spring of 2015. We also sampled 18 Andrias davidianus from a salamander farm in Beijing during the winter of 2013. Finally, samples of 69 L. catesbeianus were obtained from 2 markets in Changchun (capital of Jilin Province) and Harbin (capital of Heilongjiang Province), during the spring of 2014. All sampled amphibians were adults.

\section{Museum-preserved amphibians}

We sampled 72 preserved amphibians archived at the National Zoological Museum (Beijing) and the Shanxi Institute of Zoology. These specimens were collected from Shanxi, Sichuan, and Henan Provinces between 1961 and 1990. All specimens were preserved in $10 \%$ buffered formalin and all were adults.
DNA extraction was done following Zhu et al. (2014a). Each swab was deposited into a microtube containing $200 \mu \mathrm{l}$ of lysis buffer, which was prepared with the following concentration: $0.01 \mathrm{M} \mathrm{NaCl}, 0.1 \mathrm{M}$ EDTA, $1 \mathrm{mg} \mathrm{ml}^{-1}$ Proteinase $\mathrm{K}, 0.01 \mathrm{M}$ Tris- $\mathrm{HCl}$ ( $\mathrm{pH} 8.0$ ), and $0.5 \%$ Nonidet P-40. Each microtube was then shaken for $1 \mathrm{~min}$ with the use of a vortex mixer and then centrifuged for $1 \mathrm{~min}$ at $4208 \times \mathrm{g}$. After removing the swabs, the microtubes were centrifuged again for $1 \mathrm{~min}$ at $4208 \times g$ and later incubated first at $50^{\circ} \mathrm{C}$ for $2 \mathrm{~h}$ and subsequently at $95^{\circ} \mathrm{C}$ for $20 \mathrm{~min}$. After incubation, the microtubes were centrifuged for $3 \mathrm{~min}$ at $16831 \times g$ at $4^{\circ} \mathrm{C}$. Later, $10 \mu \mathrm{l}$ of supernatant was diluted to $10 \%$ of its original concentration by adding $\mathrm{H}_{2} \mathrm{O}$ and used as DNA template for the PCR assay.

The DNA template was amplified by a nested PCR assay (Goka et al. 2009, Bai et al. 2012, Zhu et al. 2014a). For the first amplification, we used the primers ITS1f and ITS4, which amplify the 5.8S rRNA gene along with the flanking internal transcribed spacer (ITS) of all fungi (White et al. 1990, Gaertner et al. 2009). For the second amplification, primers Bd1a and Bd2a were used to amplify the first-round PCR products (Annis et al. 2004). This PCR procedure was able to detect as little as $0.1 B d$ zoospore equivalents. Total reaction volumes were $25 \mu \mathrm{l}$, consisting of $2 \mu \mathrm{l}$ of DNA template, 10× PCR buffer $(200 \mathrm{mM} \mathrm{KCl}, 100$ 
$\mathrm{mM}\left[\mathrm{NH}_{4}\right]_{2} \mathrm{SO}_{4}, 200 \mathrm{mM}$ Tris- $\mathrm{HCl}[\mathrm{pH} 8.4], 20 \mathrm{mM}$ $\mathrm{MgSO}_{4}$, and PCR enhancer), $0.2 \mathrm{mM}$ of each dNTP, $0.4 \mathrm{mM}$ of each primer, and $1.25 \mathrm{U}$ of TransStart Taq DNA polymerase (Beijing TransGen Biotech). For the first amplification, the conditions included an initial denaturation for $5 \mathrm{~min}$ at $94^{\circ} \mathrm{C}_{i} 30$ cycles of $30 \mathrm{~s}$ at $94^{\circ} \mathrm{C}, 30 \mathrm{~s}$ at $59^{\circ} \mathrm{C}, 1 \mathrm{~min}$ at $72^{\circ} \mathrm{C}_{i}$ and a final extension for $10 \mathrm{~min}$ at $72^{\circ} \mathrm{C}$. For the second amplification, the conditions included an initial denaturation for $5 \mathrm{~min}$ at $94^{\circ} \mathrm{C} ; 30$ cycles of $30 \mathrm{~s}$ at $94^{\circ} \mathrm{C}, 30 \mathrm{~s}$ at $65^{\circ} \mathrm{C}, 30 \mathrm{~s}$ at $72^{\circ} \mathrm{C} ;$ and a final extension for $5 \mathrm{~min}$ at $72^{\circ} \mathrm{C}$.

\section{RESULTS}

$B d$ infection was detected in 12 of 1073 (1.1\%) wild amphibians, representing 5 of the 19 surveyed species. This is the first detection of $B d$ in northwestern China. In Xinjiang and in Shaanxi, 8 of 246 (3.3\%) and 4 of $74(5.4 \%)$ individuals, respectively, tested positive for $B d$. Wild amphibians from the other 6 studied provinces (766 individuals in total) were negative for $B d$, including 24 free-ranging Lithobates catesbeianus (all from Shandong). Wild amphibian species tested, provinces surveyed, and results of $B d$ assays are shown in Table 1.

$B d$ was also detected in 21 of 139 (15.1\%) captive individuals sampled from farms, food markets, and pet shops. $B d$ was detected in L. catesbeianus, Xenopus laevis, and Andrias davidianus, with evidence of $B d$ obtained from all 4 surveyed captive settings (Table 2).

All 72 preserved amphibians examined tested negative for $B d$ (Table 3). Fig. 1 shows 42 sampling sites across northern regions of China from which amphibians were investigated for evidence of $B d$.

\section{DISCUSSION}

A greater understanding of the spatial epidemiology of $B d$ is crucial to assess the importance of various mechanisms that have either contributed to its rapid emergence or its ongoing spread (Olson et al. 2013). Moreover, recognizing species or populations susceptible to chytridiomycosis is essential to inform amphibian conservation management (Bletz et al. 2015). Thus, central and northern Asia remain as the greatest gaps in the knowledge of the global distribution of $B d$ (Swei et al. 2011, Olson \& Ronnenberg. 2014).

Although intensively surveyed (723 individuals tested), evidence of $B d$ infection was not found in
Table 1. Wild amphibians tested for Batrachochytrium dendrobatidis infection in northern China

\begin{tabular}{|c|c|c|c|}
\hline $\begin{array}{l}\text { Province } \\
\text { Sampling } \\
\text { season }\end{array}$ & Species & $\begin{array}{c}\text { No. } \\
\text { examined }\end{array}$ & $\begin{array}{c}\text { No. } \\
\text { positive }\end{array}$ \\
\hline \multicolumn{4}{|l|}{ Beijing } \\
\hline \multirow{3}{*}{ Spring } & Bufo gargarizans & 21 & 0 \\
\hline & Pelophylax nigromaculatus & 36 & 0 \\
\hline & Rana chensinensis & 38 & 0 \\
\hline \multicolumn{4}{|c|}{ Heilongjiang } \\
\hline \multirow[t]{4}{*}{ Spring } & Bufo raddei & 13 & 0 \\
\hline & Rana amurensis & 6 & 0 \\
\hline & Hyla ussuriensis & 6 & 0 \\
\hline & Pelophylax nigromaculatus & 171 & 0 \\
\hline \multicolumn{4}{|l|}{ Jilin } \\
\hline \multirow[t]{4}{*}{ Spring } & Bufo gargarizans & 16 & 0 \\
\hline & Pelophylax nigromaculatus & 85 & 0 \\
\hline & Rana amurensis & 27 & 0 \\
\hline & Rana dybowskii & 20 & 0 \\
\hline \multicolumn{4}{|l|}{ Liaoning } \\
\hline \multirow[t]{8}{*}{ Spring } & Bombina orientalis & 17 & 0 \\
\hline & Bufo gargarizans & 38 & 0 \\
\hline & Bufo raddei & 23 & 0 \\
\hline & Hyla ussuriensis & 42 & 0 \\
\hline & Pelophylax nigromaculatus & 38 & 0 \\
\hline & Rana amurensis & 1 & 0 \\
\hline & Rana emeljanovi & 1 & 0 \\
\hline & Rana dybowskii & 11 & 0 \\
\hline \multirow[t]{5}{*}{ Autumn } & Glandirana emeljanovi & 14 & 0 \\
\hline & Bufo stejnegeri & 1 & 0 \\
\hline & Rana dybowskii & 2 & 0 \\
\hline & Bufo gargarizans & 25 & 0 \\
\hline & Pelophylax nigromaculatus & 6 & 0 \\
\hline \multicolumn{4}{|l|}{ Qinghai } \\
\hline \multirow{4}{*}{ Autumn } & Bufo raddei & 19 & 0 \\
\hline & Bufo gargarizans & 2 & 0 \\
\hline & Pelophylax nigromaculatus & 3 & 0 \\
\hline & Rana kukunoris & 6 & 0 \\
\hline \multicolumn{4}{|l|}{ Shandong } \\
\hline \multirow[t]{5}{*}{ Autumn } & Bufo gargarizans & 23 & 0 \\
\hline & Fejervarya limnocharis & 1 & 0 \\
\hline & Lithobates catesbeianus & 24 & 0 \\
\hline & Pelophylax nigromaculatus & 14 & 0 \\
\hline & Rana culaiensis & 3 & 0 \\
\hline \multicolumn{4}{|l|}{ Shaanxi } \\
\hline \multirow[t]{2}{*}{ Autumn } & Bufo gargarizans & 41 & 3 \\
\hline & Pelophylax nigromaculatus & 33 & 1 \\
\hline \multicolumn{4}{|l|}{ Xinjiang } \\
\hline \multirow[t]{4}{*}{ Autumn } & Bufo bufo & 5 & 0 \\
\hline & Bufotes pewzowi & 135 & 2 \\
\hline & Pelophylax terentievi & 24 & 2 \\
\hline & Rana arvalis & 38 & 4 \\
\hline \multirow[t]{3}{*}{ Summer } & Pelophylax terentievi & 30 & 0 \\
\hline & Rana asiatica & 2 & 0 \\
\hline & Bufo pewzowi & 12 & 0 \\
\hline Total & & 1073 & 12 \\
\hline
\end{tabular}

wild amphibians from northeastern China (Fig. 1). Our results are consistent with those of Wei et al. (2010), who, based on a survey of 191 Rana dybowskii (a species that is intensively hunted for human con- 
Table 2. Amphibians tested for Batrachochytrium dendrobatidis infection from amphibian food markets, farms, and pet shops in northeastern China

\begin{tabular}{|llcc|}
\hline City & Species & $\begin{array}{c}\text { No. } \\
\text { examined }\end{array}$ & $\begin{array}{c}\text { No. } \\
\text { positive }\end{array}$ \\
\hline Markets & & & \\
Beijing & Lithobates catesbeianus & 12 & 3 \\
Changchun & Lithobates catesbeianus & 36 & 2 \\
Harbin & Lithobates catesbeianus & 33 & 3 \\
Pet shops & & & \\
Beijing-1 & Ambystoma mexicanum & 7 & 0 \\
& Rana chensinensis & 10 & 0 \\
Beijing-2 & Xenopus laevis & 13 & 6 \\
Farm & Xenopus laevis & 10 & 5 \\
Beijing & Andrias davidianus & 18 & 2 \\
Total & & 139 & 21 \\
\hline
\end{tabular}

sumption), reported an absence of $B d$ in a northeastern province of China (Heilongjiang). James et al. (2015) stressed the importance in identifying regions and populations where $B d$ is absent or present at low prevalence ('cold spots'), to learn about key biotic and abiotic mechanisms underlying $B d$ distribution. For northeastern China, one of the most likely reasons why $B d$ appears to be absent in the wild is that it may never have dispersed there.

In contrast, our results from captive amphibians confirm the broad presence of $B d$ in the amphibian trade in Beijing (Bai et al. 2010), infecting Lithobates catesbeianus and Xenopus laevis (both with high

Table 3. Preserved amphibians tested for Batrachochytrium dendrobatidis infection from 3 provinces of northern China. All specimens tested negative for $B d$

\begin{tabular}{|lcc|}
\hline $\begin{array}{l}\text { Province } \\
\text { Species }\end{array}$ & $\begin{array}{c}\text { Sampling period } \\
\text { (year/month) }\end{array}$ & $\begin{array}{c}\text { No. } \\
\text { examined }\end{array}$ \\
\hline Shanxi & & \\
$\quad$ Andrias davidianus & $1986 / 09$ & 10 \\
Batrachuperus pinchonii & $1980 / 10$ & 15 \\
Bufo gargarizans & $1982 / 05$ & 4 \\
Bufo raddei & $1983 / 09$ & 3 \\
Fejervarya limnocharis & $1981 / 04$ & 3 \\
Liua tsinpaensis & $1981 / 07$ & 8 \\
Microhyla ornata & $1982 / 05$ & 7 \\
$\quad$ Nanorana quadranus & $1980 / 09$ & 4 \\
Pelophylax nigromaculatus & $1981 / 04$ & 5 \\
Rana chensinensis & $1981 / 04$ & 2 \\
Sichuan & & \\
$\quad$ Bufo gargarizans & $1979 / 09$ & 4 \\
Henan & & \\
Hyla immaculata & $1961 / 09$ & 7 \\
Total & & 72 \\
\hline
\end{tabular}

invasive potential), as well as the threatened Andrias davidianus. In addition, we detected $B d$ from $L$. catesbeianus traded in Heilongjiang and Jilin, extending the current known distribution of $B d$ in Asia (albeit for captive amphibians) farther northeast. The presence of $B d$ in all surveyed farms, food markets, and pet shops calls for urgent implementation of measures by the Chinese animal health authority to reduce the likelihood of $B d$ spill-over due to escapes or low (if not non-existent) water and residue management of aquaculture settings (Allan \& Gartenstein 2010). If $B d$ is truly absent from wild environments of northeastern China, as has been previously predicted by $B d$ niche modeling (Rödder et al. 2009, Liu et al. 2013b), many native amphibian species or populations from this region may be naïve to $B d$ and therefore possibly highly susceptible to the population effects of chytridiomycosis (Cheng et al. 2011).

Our findings are the first report of $B d$ in wild amphibians from remote areas in Xinjiang, northwestern China (Fig. 1). All 8 positive individuals were collected from 2 sites in the Irtysh River Basin, extending by nearly $500 \mathrm{~km}$ the northern known distribution of $B d$ in Asia (Swei et al. 2011). The Irtysh River flows from the Altai Mountains on the Mongolian-Chinese border, northwest to Kazakhstan, and extends far north across Russia. Further $B d$ surveys downstream of this basin may continue to increase the distribution of $B d$ northward. $B d$ was also found in 4 individuals from Changle Park in downtown Xian, Shaanxi (Fig. 1). Xian is the most populous city in northwestern China, so human-assisted introduction of $B d$ to this area should not be ruled out.

None of the 72 archived amphibian specimens showed evidence of $B d$, and thus we have no information on how long the pathogen may have been present in northern regions of China. The fixative agent formalin (in which the sampled amphibians were preserved) is capable of causing reversible cross-linking of DNA, possibly reducing the likelihood of $B d$ detection based on molecular assays (Soto-Azat et al. 2009). However, the methodology for DNA extraction and the nested PCR assay used here has recently proven to be successful in recovering and amplifying $B d$ genetic material from formalin-fixed amphibians (Zhu et al. 2014a). Bd was recently detected in specimens of Rugosa emeljanovi collected in 1911 from North Korea (Fong et al. 2015). Following a low expected detection rate of $B d$ from museum samples (Zhu et al. 2014a, Fong et al. 2015) and considering our small simple size, it is recommended that additional amphibian museum specimens be tested for $B d$ to validate our results. As the 
specimens originated from only 3 provinces of north China, more specimens from other northern provinces should be tested in future

Overall, our findings extend the known distribution of $B d$ in Central Asia farther north. Extremely low $B d$ prevalence $(1.1 \%)$ was found among wild amphibians of northwestern China, which is lower than the prevalence of $B d$ found in museum specimens $(6 \%)$ and in samples from southern China (7.6\%; Bai et al. 2012, Zhu et al. 2014a). Shin et al. (2014) suggested that swabbing often fails to detect $B d$ under conditions of low infection load. Therefore, our study may have underestimated the true prevalence of $B d$ in northern China.

Wild amphibians of northeastern China may be at a particular high risk to the effects of chytridiomycosis because of the potential historical absence of $B d$ from natural environments, compared to its extensive presence in the amphibian trade of this region (Bai et al. 2010). As a consequence, urgent actions are required to reduce the possibility of introductions of $B d$ to northeastern China (if it has not occurred already). The government should ban the transport of L. catesbeianus and $X$. laevis to this region. It is also necessary to inform the public about the impacts of releasing invasive amphibians. Investigations on the distribution of $B d$ farther north into Russia, but also research focused on isolation, DNA sequencing, and virulence testing, are recommended to further clarify the distribution and impacts of $\mathrm{Bd}$ on Asian amphibians.

Acknowledgements. We thank Hong Chen at the Shaanxi Institute of Zoology for assisting with sampling. This research was supported by grants from The Ministry of Science and Technology of China (2013FY110300) and the Beijing Natural Science Foundation (code: 5132026).

\section{LITERATURE CITED}

Allan K, Gartenstein S (2010) Keeping it clean: a Tasmanian field hygiene manual to prevent the spread of freshwater pests and pathogens. NRM South, South Hobart, TAS

Annis SL, Dastoor FP, Ziel H, Daszak P, Longcore JE (2004) A DNA-based assay identifies Batrachochytrium dendrobatidis in amphibians. J Wildl Dis 40:420-428

- Bai C, Garner TW, Li Y (2010) First evidence of Batrachochytrium dendrobatidis in China: discovery of chytridiomycosis in introduced American bullfrogs and native amphibians in the Yunnan Province, China. EcoHealth 7: 127-134

Bai CM, Liu X, Fisher MC, Garner TWJ, Li YM (2012) Global and endemic Asian lineages of the emerging pathogenic fungus Batrachochytrium dendrobatidis widely infect amphibians in China. Divers Distrib 18:307-318

Bataille A, Fong JJ, Cha M, Wogan GOU and others (2013) Genetic evidence for a high diversity and wide distribution of endemic strains of the pathogenic chytrid fungus
Batrachochytrium dendrobatidis in wild Asian amphibians. Mol Ecol 22:4196-4209

> Berger L, Speare R, Daszak P, Green DE and others (1998) Chytridiomycosis causes amphibian mortality associated with population declines in the rain forests of Australia and Central America. Proc Natl Acad Sci USA 95: 9031-9036

Bletz MC, Rosa GM, Andreone F, Courtois EA and others (2015) Widespread presence of the pathogenic fungus Batrachochytrium dendrobatidis in wild amphibian communities in Madagascar. Sci Rep 5:8633

> Cheng TL, Rovito SM, Wake DB, Vredenburg VT (2011) Coincident mass extirpation of neotropical amphibians with the emergence of the infectious fungal pathogen Batrachochytrium dendrobatidis. Proc Natl Acad Sci USA 108:9502-9507

Civis P, Vojar J, Balaz V, Kohutka A, Ulbrichova I, Dvorak V (2013) Sampling for Batrachochytrium dendrobatidis in Russia. Herpetol J 23:55-58

> Dahanukar N, Krutha K, Paingankar MS, Padhye AD, Modak N, Molur S (2013) Endemic Asian chytrid strain infection in threatened and endemic anurans of the Northern Western Ghats, India. PLoS ONE 8:e77528

Daszak P, Cunningham AA, Hyatt AD (2003) Infectious disease and amphibian population declines. Divers Distrib 9:141-150

Fei L, Ye CY, Jiang JP (2010) Introduction. In: Fei L, Ye CY, Jiang JP (eds) Colored atlas of Chinese amphibians. Sichuan Science and Technology Press, Chengdu, p 3-4

Fong JJ, Cheng TL, Bataille A, Pessier AP, Waldman B, Vredenburg VT (2015) Early 1900s detection of Batrachochytrium dendrobatidis in Korean amphibians. PLoS ONE 10:e0115656

Gaertner JP, Forstner MRJ, O'Donnell L, Hahn D (2009) Detection of Batrachochytrium dendrobatidis in endemic salamander species from Central Texas. EcoHealth 6: 20-26

> Garner TWJ, Perkins MW, Govindarajulu P, Seglie D, Walker S, Cunningham AA, Fisher MC (2006) The emerging amphibian pathogen Batrachochytrium dendrobatidis globally infects introduced populations of the North American bullfrog, Rana catesbeiana. Biol Lett 2: 455-459

Goka K, Yokoyama J, Une Y, Kuroki T and others (2009) Amphibian chytridiomycosis in Japan: distribution, haplotypes and possible route of entry into Japan. Mol Ecol 18:4757-4774

> Hyatt AD, Boyle DG, Olsen V, Boyle DB and others (2007) Diagnostic assays and sampling protocols for the detection of Batrachochytrium dendrobatidis. Dis Aquat Org 73:175-192

James TY, Toledo LF, Rödder D, da Silva Leite D and others (2015) Disentangling host, pathogen, and environmental determinants of a recently emerged wildlife disease: lessons from the first 15 years of amphibian chytridiomycosis research. Ecol Evol 5:4079-4097

Kusrini MD, Skerratt LF, Garland S, Berger L, Endarwin W (2008) Chytridiomycosis in frogs of Mount Gede Pangrango, Indonesia. Dis Aquat Org 82:187-194

Li YM, Li DM (1998) The dynamics of trade in live wildlife across the Guangxi border between China and Vietnam during 1993-1996 and its control strategies. Biodivers Conserv 7:895-914

Li YM, Wu ZJ, Duncan RP (2006) Why islands are easier to invade: human influences on bullfrog invasion in the 
Zhoushan archipelago and neighboring mainland China. Oecologia 148:129-136

Li YM, Ke ZW, Wang YH, Blackburn TM (2011) Frog community responses to recent American bullfrog invasions. Curr Zool 57:83-92

Liang G, Geng BR, Zhao EM (2004) Andrias davidianus. In: IUCN Red List of Threatened Species. Version 2015-4 www.iucnredlist.org (accessed 13 Mar 2016)

Lips KR, Brem F, Brenes R, Reeve JD and others (2006) Emerging infectious disease and the loss of biodiversity in a neotropical amphibian community. Proc Natl Acad Sci USA 103:3165-3170

Liu X, Li YM (2009) Aquaculture enclosures relate to the establishment of feral populations of introduced species. PLoS ONE 4:e6199

Liu X, McGarrity ME, Li Y (2012) The influence of traditional Buddhist wildlife release on biological invasions. Conserv Lett 5:107-114

Liu X, McGarrity ME, Bai CM, Ke ZW, Li YM (2013a) Ecological knowledge reduces religious release of invasive species. Ecosphere 4:21

Liu X, Rohr JR, Li Y (2013b) Climate, vegetation, introduced hosts and trade shape a global wildlife pandemic. Proc R Soc Lond B Biol Sci 280:20122506

Mittermeier RA, Turner WR, Larsen FW, Brooks TM, Gascon C (2011) Global biodiversity conservation: the critical role of hotspots. In: Zachos FE, Habel JC (eds) Biodiversity hotspots: distribution and protection of conservation priority areas. Springer Science \& Business Media, Berlin, p 3-22

Murray K, Retallick R, McDonald KR, Mendez D and others (2010) The distribution and host range of the pandemic disease chytridiomycosis in Australia, spanning surveys from 1956-2007. Ecological archives e091-108. Ecology 91:1557-1558

Olson DH, Ronnenberg KL (2014) Global Bd mapping project: 2014 update. FrogLog 22:17-21

> Olson DH, Aanensen DM, Ronnenberg KL, Powell CI and others (2013) Mapping the global emergence of Batrachochytrium dendrobatidis, the amphibian chytrid fungus. PLoS ONE 8:e56802

Phillott AD, Speare R, Hines HB, Skerratt LF and others (2010) Minimising exposure of amphibians to pathogens during field studies. Dis Aquat Org 92:175-185

Rödder D, Kielgast J, Bielby J, Schmidtlein S and others (2009) Global amphibian extinction risk assessment for the panzootic chytrid fungus. Diversity 1:52-66

Rodriguez D, Becker CG, Pupin NC, Haddad CFB, Zamudio KR (2014) Long-term endemism of two highly divergent lineages of the amphibian-killing fungus in the Atlantic Forest of Brazil. Mol Ecol 23:774-787

Rosenblum EB, James TY, Zamudio KR, Poorten TJ and others (2013) Complex history of the amphibian-killing chytrid fungus revealed with genome resequencing data. Proc Natl Acad Sci USA 110:9385-9390

> Savage AE, Grismer LL, Anuar S, Onn CK and others (2011) First record of Batrachochytrium dendrobatidis infecting four frog families from peninsular Malaysia. EcoHealth 8: 121-128

Schloegel LM, Picco AM, Kilpatrick AM, Davies AJ, Hyatt AD, Daszak P (2009) Magnitude of the US trade in amphibians and presence of Batrachochytrium dendrobatidis and ranavirus infection in imported North American bullfrogs (Rana catesbeiana). Biol Conserv 142: 1420-1426

Schloegel LM, Toledo LF, Longcore JE, Greenspan SE and others (2012) Novel, panzootic and hybrid genotypes of amphibian chytridiomycosis associated with the bullfrog trade. Mol Ecol 21:5162-5177

Shin J, Bataille A, Kosch TA, Waldman B (2014) Swabbing often fails to detect amphibian chytridiomycosis under conditions of low infection load. PLoS ONE 9:e111091

Skerratt LF, Berger L, Speare R, Cashins S and others (2007) Spread of chytridiomycosis has caused the rapid global decline and extinction of frogs. EcoHealth 4:125-134

Soto-Azat C, Clarke BT, Fisher MC, Walker SF, Cunningham AA (2009) Non-invasive sampling methods for the detection of Batrachochytrium dendrobatidis in archived amphibians. Dis Aquat Org 84:163-166

Soto-Azat C, Clarke BT, Poynton JC, Cunningham AA (2010) Widespread historical presence of Batrachochytrium dendrobatidis in African pipid frogs. Divers Distrib 16: $126-131$

> Soto-Azat C, Valenzuela-Sánchez A, Clarke BT, Busse K, Ortiz JC, Barrientos C, Cunningham AA (2013) Is chytridiomycosis driving Darwin's frog to extinction? PLoS ONE 8:e79862

> Swei A, Rowley JJL, Rödder D, Diesmos MLL and others (2011) Is chytridiomycosis an emerging infectious disease in Asia? PLoS ONE 6:e23179

Talley BL, Muletz CR, Vredenburg VT, Fleischer RC, Lips KR (2015) A century of Batrachochytrium dendrobatidis in Illinois amphibians (1888-1989). Biol Conserv 182:254-261

> Une Y, Kadekaru S, Tamukai K, Goka K, Kuroki T (2008) First report of spontaneous chytridiomycosis in frogs in Asia. Dis Aquat Org 82:157-160

Velo-Anton G, Rodriguez D, Savage AE, Parra-Olea G, Lips KR, Zamudio KR (2012) Amphibian-killing fungus loses genetic diversity as it spreads across the New World. Biol Conserv 146:213-218

> Vredenburg VT, Knapp RA, Tunstall TS, Briggs CJ (2010) Dynamics of an emerging disease drive large-scale amphibian population extinctions. Proc Natl Acad Sci USA 107:9689-9694

Vredenburg VT, Felt SA, Morgan EC, McNally SVG, Wilson S, Green SL (2013) Prevalence of Batrachochytrium dendrobatidis in Xenopus collected in Africa (1871-2000) and in California (2001-2010). PLoS ONE 8:e63791

- Walker SF, Bosch J, James TY, Litvintseva AP and others (2008) Invasive pathogens threaten species recovery programs. Curr Biol 18:R853-R854

Wei Y, Xu K, Zhu DZ, Chen XF, Wang XL (2010) Earlyspring survey for Batrachochytrium dendrobatidis in wild Rana dybowskii in Heilongjiang Province, China. Dis Aquat Org 92:241-244

White TJ, Bruns T, Lee S, Taylor J (1990) Amplification and direct sequencing of fungal ribosomal RNA genes for phylogenetics. In: Innis MA, Gelfand DH, Shinsky JJ, White TJ (eds) PCR protocols: a guide to methods and applications. Academic Press, New York, NY, p 315-322

> Yang H, Baek H, Speare R, Webb R and others (2009) First detection of the amphibian chytrid fungus Batrachochytrium dendrobatidis in free-ranging populations of amphibians on mainland Asia: survey in South Korea. Dis Aquat Org 86:9-13

Zhu W, Bai C, Wang S, Soto-Azat C, Li X, Liu X, Li Y (2014a) Retrospective survey of museum specimens reveals historically widespread presence of Batrachochytrium dendrobatidis in China. EcoHealth 11:241-250

Zhu W, Xu F, Bai C, Liu X and others (2014b) A survey for Batrachochytrium salamandrivorans in Chinese amphibians. Curr Zool 60:729-735 